\title{
DISTRIBUTION OF HYDRATED AND DEHYDRATED MINERALS IN LATERITIC PROFILES AND LANDSCAPES
}

\author{
TARDY Y. *, TROLARD F. **, ROQUIN C *** and NOVIKOFF A. * \\ * Institut Français de Recherche Scientifique pour le Développement en Coopération, \\ (ORSTOM), B.P. 2528 Bamako, Mali. \\ ** Université Catholique de Louvain (UCL) - Laboratoires de Géologie générale, Unité de Géochimie, \\ 3, place Louis Pasteur, B 1348 Louvain-la-Neuve, Belgique. \\ *** Centre de Géochimie de la Surface (CNRS), 1, rue Blessig, 67084 Strasbourg, France.
}

Lateritic profiles and particularly bauxites, ferricretes and kaolinitic mantles, show successions of horizons more or less indurated and sequences of minerals which are in different hydration states. In the unsaturated zone located above the ground water table, the less hydrated phases are interstratified between two horizons containing more hydrated minerals. This general distribution is explained by seasonal fluctuations of the thermodynamic activity of water within the profiles. Such fluctuations also explain how duricrusts such as ferricretes for example, are formed, conserved or destroyed (Tardy and Novikoff, 1988, Tardy et al., 1988).

In lateritic profiles several sequences of hydrated-dehydrated-hydrated minerals have been observed : gibbsite - kaolinite - gibbsite, in oxisols; goethite - hematite - goethite, in ferricretes; gibbsite boehmite - gibbsite in lateritic bauxites or even : kaolinite - diaspore (boehmite) - gibbsite in karst bauxites. These mineral sequences are not always complete, however the maxima of boehmite, diaspore and sometimes corundum, always correspond to the maxima of hematite and to the optimal development of ooids and pisoids (Bardossy, 1982). A similar process occurs in manganese duricrusts in which the sequence manganite pyrolusite - cryptomelane is observed (Weber et al., 1979; Nahon et al., 1984). In ferricretes in which the mechanism of hydrationdehydration-rehydration was demonstrated (Nahon,
1976; Tardy and Nahon, 1985), the optimal induration and accumulation of iron correspond to the zone of nodule formation, and to the maximum value of the ratio hematite/goethite. The secondary goethite which appears at the top of the profiles corresponds to a rehydration process which is thought to be responsible for the destruction of the original nodules and for ferricrete dismantling (Nahon, 1976).

According to hydration reactions, goethite, manganite and gibbsite are hydrated minerals while hematite, pyrolusite, boehmite and kaolinite are dehydrated minerals. Hydrated minerals appear at the bottoms of profiles, close to the ground water table, or downslope where the unsaturated layer is reduced. They also appear again close to the surface of thick profiles, at the edges of large channels, temporarily hydrated during the wet season. Dehydrated minerals appear preferentially in the intermediate part of the unsaturated zone (Tardy et al., 1988). They form concretions, almost always accompany induration, and contribute to duricrustformation.

\section{Chemical composition and climatic} distribution of goethite and hematite

Schwertmann (1988) analyzed occurrence and formation of iron oxides in various pedoenvironments. In weathering profiles, the ratio 
of hematite to hematite plus goethite $(\mathrm{Hm} /(\mathrm{Hm}+$ Go)) is controlled by temperature, humidity of the soil atmosphere, $\mathrm{pH}$, organic matter content, altitude and latitude. Some of these factors such as altitude (elevation) or latitude include the effect of temperature and moisture. Furthermore, at a regional scale, some parameters such as soil $\mathrm{pH}$ and organic matter content are closely related to rainfall.

Therefore, it is difficult to separate their specific influence. Soil temperature is regulated by climatic factors such as latitude, altitude and continentality. The relative humidity of the soil atmosphere, that is, the thermodynamic activity of water, is controlled by rainfall, evaporation, permeability, pore size, and depth of ground water table.

If $\mathrm{pH}$ and organic matter are typically kinetic parameters, temperature and activity of water are both thermodynamic factors which have to be taken into account as well. In fact, the mass action law applied to the equilibrium hematite-goethite, yields :

$\mathrm{FeO}_{1.5}$ (hematite) $+0.5 \mathrm{H}_{2} \mathrm{O}$ (water) $=\underset{\text { (goethite) }}{\mathrm{FeOOH}}$

$\mathrm{K}(\mathrm{T})=[\mathrm{FeOOH}] /\left[\mathrm{FeO}_{1.5}\right]\left[\mathrm{H}_{2} \mathrm{O}\right]^{0.5}$

The constant of the mass action law $(\mathrm{K}(\mathrm{T}))$ is a function of temperature and the equilibrium conditions are chiefly dependent on the activity of water $\left(a_{w}=\left[\mathrm{H}_{2} \mathrm{O}\right]\right)$. However hematite-goethite equilibria are also regulated by the activity of the two solid phases : $[\mathrm{FeOOH}]$ for goethite and $\left[\mathrm{FeO}_{1.5}\right]$ for hematite. Solid phase activities are determined by three conditions which have to be taken into consideration separately : purity, chemical composition (aluminum content) and grain size.

\section{Distribution of Al-hematite and Al-goethite in laterites}

The aluminum contents of goethite and hematite should be regarded as a function of the nature of the other associated minerals. In goethites of red soils, the substitution rates diminish when the climate becomes less humid or more arid and percolating solutions are richer in silica (Tardy, 1971). This is probably due to the presence of kaolinite which controls the chemical composition of the solution (Trolard and Tardy, 1989).

Compositions range from 2 to 20 mole percent of $\mathrm{AlO}(\mathrm{OH})$ in goethites of ferricretes and other soils in which kaolinite is present. Compositions range from 18 to 27 mole percent in goethites associated with gibbsite in bauxites. Hematite generally has less substitution than goethite and both are less aluminous when kaolinite and quartz are present than when gibbsite forms.

Obviously, the aluminum contents of goethites and hematites are controlled by the activity of aluminum in solution which in turn is determined by the solubility of aluminous minerals, that is gibbsite and kaolinite. It turns out that the relative stability fields of goethite and hematite may depend on their degree of Al-substitution which are dependent on the stability of the other aluminous minerals associated with them. The conditions of formation of goethite and hematite may be ultimately determined by the activity of silica in solution and by the activity of water in pores in which these minerals form.

\section{Thermodynamic stability field of Al-goethite and Al-hematite}

Stability fields of Al-goethite and AI-hematite, gibbsite, boehmite and kaolinite can be considered to be a function of particle size, temperature and the thermodynamic activity of water (Trolard, 1988; Trolard and Tardy, 1987).

For a given temperature, $\mathrm{T}$, and according to the equilibrium conditions expressed earlier, stability diagrams are constructed as a function of the aluminum content and water activity. When temperature decreases, several modifications are observed. The stability field of the association of Al-hematite and boehmite is reduced. The stability field of the association of the Al-goethite and gibbsite becomes larger. For a given composition and a given water activity, the Al-substitution in Al-goethite associated with gibbsite decreases. When temperature increases the contrary is observed. The stability field of Al-goethite is reduced, gibbsite disappears near $40^{\circ} \mathrm{C}$ and is replaced by boehmite; the stability field of Al-hematite is extended; at about $75^{\circ} \mathrm{C}$, Al-goethite disappears.

For a constant water activity $\left(\left[\mathrm{H}_{2} \mathrm{O}\right]=1\right.$, for example) and for a given composition $\left(\mathrm{Al}_{2} \mathrm{O}_{3}\right.$ / $\left.\left(\mathrm{Fe}_{2} \mathrm{O}_{3}+\mathrm{Al}_{2} \mathrm{O}_{3}\right)\right)$ the degree of substitution of diaspore in Al-goethite, when Al-goethite is associated with gibbsite, increases with temperature. The degree of substitution of corundum in Al-hematite also increases with temperature.

An increase in temperature and a decrease in water activity, have qualitatively similar effects on the stability fields. This is because the entropy and the heat capacity of water in gibbsite $\left(\mathrm{Al}_{2} \mathrm{O}_{3} .3 \mathrm{H}_{2} \mathrm{O}\right)$, goethite $\left(\mathrm{Fe}_{2} \mathrm{O}_{3} \cdot \mathrm{H}_{2} \mathrm{O}\right)$ and boehmite $\left(\mathrm{Al}_{2} \mathrm{O}_{3} \cdot \mathrm{H}_{2} \mathrm{O}\right)$ 
are smaller than those characterizing liquid water.

\section{CONCLUSIONS}

It is clear that the chemical potential of water plays a major role in the transformation of gibbsite into boehmite, for the transformation of boehmite into corundum at low temperature (Bardossy, 1982) and for the transformation of goethite into hematite (Tardy and Nahon, 1985).

Equilibrium diagrams show the conditions of formation of $\mathrm{Al}$-goethites, Al-hematites, gibbsite and boehmite in laterites, bauxites and ferricretes. The stability fields of the various associations are presented in terms of the thermodynamic activity of water, temperature and particle size. The diagrams allow for substitutions of $\mathrm{Al}$ for $\mathrm{Fe}$ in goethite and hematite and we have regarded these solid solutions as ideal.

In summary, the stability diagrams based on activity of water and temperature permit the following conclusions.

(i) Dehydration transformations of the type : (goethite ---> hematite), (gibbsite -.-> boehmite -..-> corundum), (gibbsite ---> kaolinite), can be induced by a decrease in the thermodynamic activity of water (at constant $\mathrm{T}$ ), by an increase in temperature (at constant $\mathrm{a}_{\mathrm{W}}$ ) or by $\mathrm{a}_{\mathrm{W}}$ decreasing and $\mathrm{T}$ increasing simultaneously.

(ii) A decrease in water activity has a similar effect to an increase in temperature. The successions of mineral phases and parageneses are similar in both cases : Al-goethite -.-> Al-goethite + Al-hematite $\ldots$ Al-hematite, for systems of low aluminum content and, Al-goethite + gibbsite -.-> Al-goethite + boehmite ---> Al-hematite ---> (Fe-corundum), for systems of high aluminum content.

(iii) When minerals are in association such as (Al-goethite + gibbsite) or (Al-goethite + Al-hematite), the Al-goethite or Al-hematite compositions do not depend on the composition of the system but only on water activity or temperature. The aluminum contents increase as water activity decreases or as temperature increases.

(iv) When Al-goethite and boehmite are stable together, the Al-goethite composition does not depend on the composition of the system nor on temperature and water activity. It is remarkable that, in this case, the aluminum content of goethite is almost fixed (for example, $\left(\mathrm{Al}_{0.25} \mathrm{Fe}_{0.755}\right) \mathrm{OOH}$ at $25^{\circ} \mathrm{C}$ ). The same considerations are valid for the association of hematite and corundum.

(v) When only A1-goethite or Al-hematite are stable, their aluminum content depends neither on water activity nor on temperature. The Al-goethite and Al-hematite compositions depend then only on the ratio of $\left(\mathrm{Al}_{2} \mathrm{O}_{3} /\left(\mathrm{Al}_{2} \mathrm{O}_{3}+\mathrm{Fe}_{2} \mathrm{O}_{3}\right)\right)$ in the system.

(vi) The stability field of baolinite in the presence of gibbsite or boehmite is dependent both on activity of water and activity of silica. At $25^{\circ} \mathrm{C}$ and $100 \mathrm{kPa}$ total pressure, if the silica activity is lower than $10^{-4.57}$, kaolinite is not stable whatever the water activity is. In the dissolved silica activity interval $\left[10^{-4.57}\right.$ to $\left.10^{-4.50}\right]$ gibbsite, then kaolinite and finally boehmite can be stabilized, successively, when the water activity decreases. In the interval $\left[10^{-4.50}\right.$ to $\left.10^{-4.0}\right]$ only kaolinite and boehmite are stable. For a decreasing water activity, the stability field of boehmite progressively overlaps the kaolinite domain (Trolard and Tardy, 1989).

(vii) The presence of kaolinite instead of gibbsite and boehmite in soils or weathering profiles should induce changes in the Al-content of aluminous goethite, as the equilibrium with kaolinite decreases when water activity or silica activity increases. This may explain why, in general, goethites are poorer in aluminum downslope, in lowlands and in hydromorphic soils compared to ultisols or oxisols located at the top of profiles or in high landscape situations where the aqueous pore solutions are depleted in silica.

(viii) The iron content in kaolinite is shown to be dependent on the water activity and on dissolved silica activity. An increase of water activity at a fixed silica activity, or an increase of silica activity at a fixed water activity should induce an increase of iron relative to aluminum in the ferruginous kaolinite.

Clearly the chemical composition of goethite, hematite and kaolinite are controlled by equilibrium with other phases present in the system, by silica activity regulated by the rate of percolating waters, by temperature and by the activity of water which is a function of climatic and regional drainage conditions.

\section{ACKNOWLEDGEMENT}

The present study was carried out as part of the ATP "Laterites" (CNRS), of the Laterite Project of the Programme PIRAT (INSU-ORSTOM) and in the general framework of EUROLAT (European Network of Laterite Study).

\section{REFERENCES}

BARDOSSY G., 1982. Karst bauxites. Bauxite deposits on carbonate rocks. Elsevier, Scientific Publishing Co., Amsterdam-Oxford-New York, Developments in Economy 
Geology, 14, 441 pp.

NAHON D., 1976. Cuirasses ferrugineuses et encroutements calcaires au Sénégal Occidental et en Mauritanie, systèmes évolutifs : géochimie, structures, relais et coexistence. Sci. Géol. Mém., 44, 232 pp.

NAHON D., BEAUVAIS A., NZIENGUI-MAPANGOU P. and DUCLOUX J., 1984. Chemical weathering of Mn-garnets under lateritic conditions in northwest Ivory Coast (West Africa). Chem. Geol., 45 : 53-71.

SCHWERTMANN U, 1988. Goethite and hematite formation in the presence of clay minerals and gibbsite at $25^{\circ} \mathrm{C}$. Soil Sci. Soc. Am. J., 52: 288-291.

TARDY Y., 1971. Characterization of the principal weathering types by the geochemistry of the waters from some european and african crystalline massifs. Chem. Geol., 7: 253-271.

TARDY Y. and NAHON D., 1985. Geochemistry of laterites stability of Al-goethite, Alhematite and Fe-kaolinite in bauxites and ferricretes: an approach to the mechanism of concretion formation. Am. J. Sci., 285: 865-903.

TARDY Y. and NOVIKOFF A., 1988. Activité de l'eau et déplacement des équilibres gibbsite - kaolinite đans les profils latéritiques. C. R. Acad. Sci., Paris, 306, série II, 1988: 39-44.

TARDY Y., BARDOSSY G. and NAHON D., 1988. Fluctuations de l'activité de l'eau et successions de minéraux lydratés et déshydratés au sein des profils latéritiques ferrugineux et bauxitiques. C. R. Acad. Sci., Paris, 307, série II, $1988:$ 753-759.

TROLARD F., 1988. Physicochimie des cuirasses latéritiques. Domaines de stabilité des oxydes et hydroxydes de fer et d'aluminium. Thèse Univ. Louis Pasteur, Strasbourg, $213 \mathrm{pp}$.

TROLARD F. and TARDY Y., 1987. The stabilities of gibbsite, boehmite, aluminous goethites and aluminous haematites in bauxites, ferricretes and laterites as function of water activity, temperature and particle size Geochim. Cosmochim. Acta, 51: 945-957.

TROLARD F. and TARDY Y., 1989. A model of Fe3+-kaolinite, A13+-goethite,A13+-hematite equilibria in laterites. Clay Miner., 24: 1-21.

WEBER F., LECLERC J. and MILLOT G., 1979. Epigénies manganésiferres successives dans le gisement de Moanda (Gabon). Sci. Géol. Bull., 32: 147-164. 